\title{
EFEKTIVITAS FORUM DISKUSI PADA E-LEARNING BERBASIS MOODLE UNTUK MENINGKATKAN PARTISIPASI BELAJAR
}

\section{Soraya Fatmawati}

Universitas Teknologi Yogyakarta

Email: soraya.fatmawati@staff.uty.ac.id

\begin{tabular}{|c|c|}
\hline Info Artikel & Abstract \\
\hline $\begin{array}{l}\text { Sejarah Artikel: } \\
\text { Diterima } 2 \text { Mei } 2019 \\
\text { Direvisi } 30 \text { Mei } 2019 \\
\text { Disetujui 1 Juni } 2019\end{array}$ & $\begin{array}{l}\text { The study aims to find out the effectiveness of the discussion forum on Moodle based e- } \\
\text { learning to improve students learning participation. The study employs pre-experiment } \\
\text { method with one group pretest-posttest design and analysis method uses non-parametric } \\
\text { statistics with T-test. The study is conducted at Information Technology Department of } \\
\text { Faculty of Education at University of Technology Yogyakarta. The research sample is } \\
\text { taken from the fourth semester student of Information Technology Education Department }\end{array}$ \\
\hline $\begin{array}{l}\text { Keywords: } \\
\text { E-learning, learning } \\
\text { participation, discussion }\end{array}$ & $\begin{array}{l}\text { who enroll theory course. Instrument used in this study is guided observation to observe } \\
\text { students learning participation with } 2 \text { answer alternatives. The study result shows that } \\
\text { discussion forum on Moodle based e-learning can improve students learning participation } \\
\text { compared to discussion occurred in the conventional classroom or classical discussion } \\
\text { with the significant result of improvement for about } 37 \% \text {. }\end{array}$ \\
\hline
\end{tabular}

\begin{abstract}
Abstrak
Tujuan dari penelitian ini adalah mengetahui efektifitas dari penggunaan forum diskusi dalam e-learning berbasis Moodle untuk meningkatkan partisipasi belajar mahasiswa. Metode penelitian yang digunakan adalah metode pre eksperimen dengan one group pretest-posttest design dan dianalisis menggunakan statistik non parametrik dengan uji Ttest. Lokasi penelitian pada Program Studi Pendidikan Teknologi Informasi (PTI) Fakultas Pendidikan Universitas Teknologi Yogyakarta. Sampel yang digunakan dalam penelitian ini adalah mahasiswa Prodi PTI Semester 4 yang menempuh Mata Kuliah Teori. Instrumen yang digunakan adalah pedoman observasi untuk mengamati partisipasi belajar mahasiswa dengan menggunakan 2 alternatif jawaban. Hasil penelitian ini menunjukkan bahwa forum diskusi pada e-learning berbasis Moodle mampu meningkatkan partisipasi belajar mahasiswa jika dibandingkan dengan diskusi yang terjadi dikelas konvensional atau klasikal secara tatap muka dengan nilai peningkatan sebesar $37 \%$.
\end{abstract}


Fatmawati, Soraya

EFEKTIVITAS FORUM DISKUSI PADA E-LEARNING BERBASIS MOODLE UNTUK MENINGKATKAN ... REFLEKSI EDUKATIKA : Jurnal Ilmiah Kependidikan, Volume 9, Nomor 2, Juni 2019, hlm 210-216

\section{PENDAHULUAN}

Berdasarkan UU No. 20 Tahun 2003 tentang Sistem Pendidikan Nasional menerangkan bahwa sistem pendidikan nasional adalah keseluruhan komponen pendidikan yang saling terkait secara terpadu untuk mencapai tujuan pendidikan nasional. Kunci dalam definisi tersebut terletak pada keseluruhan komponen pendidikan yang saling terkait. Komponen pendidikan beberapa diantaranya adalah strategi pembelajaran dan media pembelajaran. Kedudukan media pembelajaran terletak di dalam strategi pembelajaran. Berkembangnya ternologi informasi yang ada saat ini, berpengaruh pula terhadap media dan strategi pembelajaran.

E-learning merupakan produk yang lahir dari berkembangnya teknologi informasi yang merambah ke dunia pendidikan. E-learning atau electronic learning merupakan sebuah pembelajaran yang memanfaatkan bantuan elektronik. Alat-alat elektronik yang mulanya berupa televisi, CD-ROM, radio, kaset dan lainnya, berkembang seiring dengan kemajuan teknologi. Definisi e-learning sendiri sangatlah bervariasi dan belum memiliki standar yang baku, tetapi jika dibandingkan dengan pembelajaran klasikal keuntungan yang dapat diperoleh adalah pada sisi fleksibilitasnya (Surdjono, 2013). Selain sisi fleksibilitasnya, mengacu pada era perkembangan teknologi saat ini keuntungan penggunaan e-learning juga dilihat dari segi kemudahan akses (accessibility). Kemudahan akses tersebut memunculkan istilah baru yang juga merupakan bagian dari e-learning yaitu mobile learning. Georgiev \& Smrikarov juga mengatakan hal yang serupa seperti dikutip oleh Ibrahim \& Ishartiwi (2017) menyatakan bahwa mobile learning merupakan bagian dari pembelajaran elektronik atau e-learning. Kehadiran pembelajaran elektronik yang dikemas secara mobile memungkinkan peserta didik untuk mempelajari sebuah materi pembelajaran kapanpun dan dimanapun.

Pembelajaran yang dapat diakses dimanapun dan kapanpun membutuhkan perangkat dan sarana prasarana yang mendukung sistem pembelajaran tersebut. Sejalan dengan pernyataan tersebut, LearnFrame.com yang dikutip Andrizal \& A. Arif (2017) menulis bahwa e-learning adalah sistem pendidikan yang menggunakan aplikasi elektronik untuk mendukung belajar mengajar menggunakan media internet, jaringan komputer maupun komputer stand alone. Penggunaan internet memudahkan peserta didik untuk belajar kapan saja. Perkembangan e-learning yang didukung dengan menggunakan jaringan internet, menghasilkan semakin banyak tersedianya perangkat lunak yang mendukung jalannya sistem pembelajaran tersebut. Diantaranya ada LMS (Learning Management System), LCMS (Learning Content Management System) dan SLN (Social Learning Network). Masing-masing perangkat lunak tersebut membantu pendidik untuk membuat sistem e-learning menjadi semakin efektif. Beberapa contoh yang termasuk dalam LMS ada Atutor, Moodle dan lain sebagainya. LCMS ada claroline dan e-doceo solutions sementara SLN ada salahsatunya yaitu Edmodo. Diantara sekian banyak perangkat lunak pendukung pembelajaran berbasis elearning, yang paling populer dikenal dan banyak digunakan dalam pembelajaran adalah Edmodo dan Moodle. Dharmawati seperti dikutip oleh Rulviana (2018) mengatakan bahwa Edmodo merupakan bentuk e-learning yang dikembangkan berdasarkan prinsip-prinsip pengelolaan kelas berbasis kelompok dan sosial media sehingga, Edmodo yang berbentuk menyerupai facebook tersebut dikembangkan agar dapat dimanfaatkan oleh guru, siswa maupun orangtua. Selain Edmodo, salah satu yang juga populer adalah Moodle (modular object oriented dynamic learning environment). Moodle merupakan sebuah platform belajar yang didesain untuk digunakan oleh para pendidik, administrator dan peserta didik sebagai sebuah sistem terintegrasi yang andal dan aman. Moodle pertama kali dibuat pada akhir tahun 2001 oleh Martin Dougiamas dengan versi 1.0 dirilis pada bulan Agustus 2002 (Hakim, 2016).

E-learning berbasis Moodle banyak dipakai di institusi-institusi pendidikan mulai dari tingkat menengah hingga perguruan tinggi. Salah satu Perguruan Tinggi yang menggunakan e-learning berbasis Moodle ini adalah Universitas Teknologi Yogyakarta (UTY). Pada Tahun Akademik 2017/2018 secara resmi elearning berbasis Moodle ini diterapkan pada pelaksanaan perkuliahan yang ada di UTY. Penggunaan e-learning berbasis Moodle ini lebih banyak digunakan pada mata kuliah teori daripada mata kuliah praktek. Mekanisme pelaksanaan e-learning yang ada di UTY dilakukan secara campuran (blended) dengan 
Fatmawati, Soraya

EFEKTIVITAS FORUM DISKUSI PADA E-LEARNING BERBASIS MOODLE UNTUK MENINGKATKAN ... REFLEKSI EDUKATIKA : Jurnal Ilmiah Kependidikan, Volume 9, Nomor 2, Juni 2019, hlm 210-216

pembelajaran klasikal. Ketentuan penggunaan elearning dalam perkuliahan yang ada di UTY yaitu 14 kali pertemuan, 10 kali tatap muka dan 4 kali menggunakan e-learning.

E-learning yang digunakan di UTY merupakan LMS yang berbasis Moodle dengan alamat website elearning.uty.ac.id. Dalam Moodle ini, ada banyak aktivitas-aktivitas yang dapat dimanfaatkan oleh pengajar dalam menyampaikan perkuliahan. Diantaranya yaitu: memasukkan materi perkuliahan, membuat dan mengelola tugas mahasiswa, membuat kuis, memanfaatkan forum diskusi, chat dan lain sebagainya. Beberapa aktivitas tersebut dapat divariasikan penggunaannya sesuai dengan waktu yang dialokasikan untuk pemanfaatan elearning dalam perkuliahan satu semester.

Berdasarkan data yang diperoleh dari mahasiswa dengan menggunakan metode wawancara dan observasi, ada beberapa hal yang ditemukan terkait penggunaan e-learning antara lain: (1) sebagian besar mata kuliah teori telah menggunakan e-learning dalam pelaksanaan perkuliahannya. (2) belum semua pengajar menggunakan e-learning sesuai dengan jumlah aktivitas yang dianjurkan yaitu 4 kali. (3) belum maksimalnya penggunaan aktivitas-aktivitas yang ada pada e-learning berbasis Moodle ini. (4) banyaknya masalah teknis yang diakibatkan oleh mahasiswa itu sendiri. (5) mahasiswa termotivasi untuk mengikuti perkuliahan dengan menggunakan e-learning dari pada tatap muka seperti biasa. (6) mahasiswa lebih senang menggunakan e-learning karena tidak mengharuskan mahasiswa datang ke kampus untuk mengikuti perkuliahan. (7) dari banyak aktivitas yang ada di e-learning mahasiswa tertarik untuk mencoba menggunakan forum.

Dari hasil wawancara singkat dengan mahasiswa ditemukan data bahwa aktivitas yang sebagian besar digunakan dalam e-learning hanya aktivitas mengunduh materi maupun menggunggah tugas yang telah dikerjakan melalui aktivitas assignment. Sementara aktivitas lain seperti pemberian kuis, forum diskusi, chat maupun aktivitas yang lainnya jarang digunakan. Idealnya e-learning memfasilitasi pengajar untuk lebih dekat dengan mahasiswa menggunakan berbagai variasi aktivitas yang ada, namun pada kenyataannya pengajar belum memanfaatkan elearning secara optimal. Berdasarkan beberapa hal yang ditemukan pada saat pelaksanaan perkuliahan berbantuan e-learning, ditemukan beberapa permasalahan yang menjadi sorotan yaitu belum maksimalnya penggunaan aktivitasaktivitas yang ada pada elearning dan mahasiswa tertarik untuk mencoba menggunakan forum diskusi.

Beberapa aktivitas yang ada dalam moodle yang dapat digunakan oleh pengajar salah satunya ada forum diskusi. Diskusi sendiri adalah salah satu jenis metode pembelajaran yang menghendaki sekelompok siswa untuk membahas suatu masalah ditinjau dari berbagai segi atau sudut pandang (Gafur, 2012). Suryosubroto dikutip oleh Firmansyah mengatakan bahwa diskusi adalah percakapan ilmiah oleh beberapa orang yang tergabung dalam satu kelompok untuk saling bertukar pendapat tentang suatu masalah atau bersamasama mencari pemecahan mendapatkan jawaban dan kebenaran atas suatu masalah (Firmansyah, 2017). Sehingga, dalam satu kelompok tersebut akan tercapai sebuah keputusan final yang telah disetujui oleh semua anggota kelompok. Sejalan dengan Suryosubroto, penelitian Gokhale dalam Luritawaty menemukan bahwa kelebihan diskusi tidak hanya meningkatkan daya tarik antar partisipan tetapi juga dapat meningkatkan cara berpikir kritis (Luritawaty, 2016). Idealnya secara teori, diskusi dilaksanakan secara tatap muka melibatkan seluruh anggota kelompok dan saling aktif mengemukakan pendapatnya. Namun pada prakteknya dikelas, diskusi lebih banyak didominasi oleh peserta didik yang aktif saja.

Dalam e-learning berbasis Moodle terdapat menu aktivitas yang dapat digunakan untuk berdiskusi ialah Forum. Aktivitas Forum memungkinkan seluruh anggotanya dalam hal ini adalah mahasiswa yang ikut dalam perkuliahan teori tertentu untuk saling berdiskusi sesuai dengan tema yang telah ditentukan oleh pengajar atau course creator sebelumnya. Semua anggota dalam forum diskusi dapat mengangkat topik tertentu maupun menanggapi topik yang telah diangkat oleh teman lainnya. E-learning yang berkonsep belajar dimana saja dan kapan saja tanpa perlu adanya tatap muka memungkinkan anggota forum yang cenderung pendiam atau pasif untuk dapat menyampaikan pendapatnya juga. Sehingga, ketika pembelajaran di kelas secara tatap muka peserta didik yang pasif sebagai anggota forum tidak berani menyampaikan pendapat dengan e-learning memungkinkan anggota forum yang pasif untuk ikut berpartisipasi dalam diskusi. 
Fatmawati, Soraya

EFEKTIVITAS FORUM DISKUSI PADA E-LEARNING BERBASIS MOODLE UNTUK MENINGKATKAN ... REFLEKSI EDUKATIKA : Jurnal Ilmiah Kependidikan, Volume 9, Nomor 2, Juni 2019, hlm 210-216

Cara pembuatan Forum dalam e-learning berbasis Moodle ini ialah pengajar atau course creator memilih pada bagian "Add an Activity" kemudian memilih Forum (Surdjono, 2013). Course creator dapat memasukkan judul forum, penjelasan terkait forum diskusi yang akan dibuat sesuai dengan kebutuhan termasuk juga rentang waktu dimulai hingga berakhirnya forum diskusi tersebut. Peran mahasiswa dalam forum diskusi adalah dengan membuat sebuah topik yang sesuai dengan tema yang dibuat oleh course creator dan dapat menganggapi topik-topik lain yang dibuat oleh rekannya. Penggunaan aktivitas forum diskusi dalam e-learning bertujuan agar mampu meningkatkan motivasi dan partisipasi belajar mahasiswa. Partispasi belajar mahasiswa yang menggunakan kelas klasikal secara tatap muka pada umumnya cenderung didominasi oleh mahasiswa-mahasiwa yang aktif saja. Sementara mahasiswa yang kurang aktif bahkan cenderung pasif, partisipasi dalam kelas tidak nampak. Sehingga forum diskusi dalam e-learning ini menjadi solusi yang tepat untuk meningkatkan partisipasi belajar mahasiswa dalam kelas.

Partisipasi belajar atau dalam bahasa sederhana merupakan keikutsertaan seseorang dalam belajar. Menurut Sudjana (2005) partisipasi belajar merupakan pengikutsertaan seseorang untuk melakukan atau pengambilan bagian dari sesuatu yang harus dilakukan oleh pelakunya. Hal tersebut menunjukkan bahwa partisipasi belajar adalah keikutsertaan dalam hal ini adalah mahasiswa untuk mau terlibat dalam pembelajaran. Partisipasi tersebut diukur dari seberapa besar keterlibatan anggota dalam aktivitas-aktivitas kelompok. Dalam penelitian Mustajab dan Sriyono (2010) tentang penerapan metode pembelajaran cooperative script terhadap partisipasi belajar siswa menunjukkan bahwa partisipasi belajar akan meningkat jika di dalam pelaksanaan pembelajaran menggunakan metode pembelajaran yang berbeda dari biasanya. Dalam penelitian lain oleh Mayasari (2016) yang bertema penerapan model pembelajaran contextual teaching and learning (CTL) menunjukkan bahwa partisipasi sekaligus minat belajar dapat meningkat dengan penggunaan model pembelajaran yang berbeda dari biasanya. Kedua penelitian tersebut menghasilkan kesimpulan bahwa penerapan metode pembelajaran yang berbeda dari biasanya akan mampu meningkatkan partisipasi belajar peserta didik. Sementara dalam penelitian lain yang lebih spesifik menunjukkan bahwa partisipasi belajar meningkat tidak hanya menggunakan metode maupun model pembelajaran yang bervariasi namun juga dapat menggunakan media pembelaran yang berbeda. Hal tersebut ditemukan oleh Panjaitan (2017) yang telah meneliti tentang pemanfaatan sebuah media pembelajaran. Dalam penelitian tersebut dikatakan bahwa partisipasi belajar siswa mengalami peningkatan setelah pembelajaran dilaksanakan dengan menggunakan sebuah media pembelajaran berupa kartu kendali. Pada penelitian ini, partisipasi belajar mahasiswa yang kurang nampak di kelas klasikal secara tatap muka diupayakan untuk menggunakan forum diskusi dalam e-learning. Sehingga, kelas tidak hanya didominasi oleh mahasiswa yang aktif saja namun semua mahasiwa dapat ikut berpartisipasi dalam perkuliahan. Banyak faktor yang menyebabkan mahasiswa cenderung pasif ketika berada di kelas tatap muka. Penggunaan forum diskusi dalam moodle dianggap mampu untuk meningkatkan partisipasi belajar mahasiswa.

Tujuan penelitian ini adalah untuk mengetahui tingkat efektivitas dari penggunaan forum diskusi dalam e-learning berbasis Moodle untuk meningkatkan partisipasi belajar. Diharapkan dari hasil penelitian ini mampu memberikan pemahaman kepada pengajar atau course creator bahwa forum diskusi dalam elearning berbasis Moodle sangat mampu untuk meningkatkan partisipasi belajar mahasiswa.

\section{METODE PENELITIAN}

Metode Penelitian

Penelitian ini menggunakan metode penelitian pre eksperimen dengan desain OneGroup Pretest-Posttest Design. Metode ini menjelaskan bahwa dalam suatu kelompok diawali dengan adanya pretest kemudian diberi perlakuaan dan selanjutnya diobservasi hasilnya (Sugiyono, 2017). Hasil dari pretest dengan posttest akan diukur, apakah ada peningkatan hasil atau tidak.

Waktu dan Lokasi Penelitian

Waktu penelitian ini adalah pada Semester Genap Tahun Akademik 2017/2018. Analisis masalah dilakukan diawal semester untuk menentukan seberapa penting penelitian ini. Lokasi penelitian adalah pada Program Studi Pendidikan Teknologi Informasi Fakultas Pendidikan Universitas Teknologi Yogyakarta. 
Fatmawati, Soraya

EFEKTIVITAS FORUM DISKUSI PADA E-LEARNING BERBASIS MOODLE UNTUK MENINGKATKAN ... REFLEKSI EDUKATIKA : Jurnal Ilmiah Kependidikan, Volume 9, Nomor 2, Juni 2019, hlm 210-216

\section{Subjek Penelitian}

Subjek yang digunakan dalam penelitian ini adalah mahasiswa Prodi Pendidikan Teknologi Informasi yang menepuh Mata Kuliah Teori sebanyak 24 orang mahasiswa.

Teknik Pengumpulan Data

Pengumpulan data dalam penelitian ini menggunakan instrumen observasi dengan 2 alternatif jawaban. Masing-masing jawaban memiliki 2 bobot penilaian, skor 1 untuk jawaban YA dan skor 0 untuk jawaban TIDAK. Prosedur Penelitian

Pada desain metode eksperimen ini, subjek dikenakan dua kali pengukuran pretest dan posttest. Pretest dilakukan sebelum mahasiswa melakukan diskusi secara online melalui e-learning berbasis Moodle dan posttest dilakukan setelah mahasiswa melalukan diskusi secara online melalui e-learning berbasis Moodle.

Tahap-tahap metode pre eksperimen adalah sebagai berikut: (1) pretest dengan melakukan observasi terlebih dahulu terhadap 24 orang mahasiswa yang akan melakukan diskusi secara online dengan menggunakan elearning berbasis moodle. (2) perlakuan (treatment) yaitu dengan memberikan instruksi kepada mahasiswa untuk berdiskusi secara online memalui elearning Moodle. (3) posttest setelah pemberian perlakuan dengan tujuan untuk mengetahui apakah partisipasi dalam forum diskusi online dapat meningkat. Posttest dilakukan dengan menggunakan observasi. Prosedur analisis data dengan menggunakan paired sample t-test.

Validitas dan Reliabilitas Instrumen

Uji validitas instrumen dilakukan dengan cara judgement experts dan hasilnya dianalisis dengan menggunakan rumus Aiken's $V$. Hasil perhitungan uji validitas instrumen menunjukkan nilai rata-rata 0,667 yang termasuk ke dalam nilai dengan kategori tinggi. Reliabilitas instrumen diuji dengan menggunakan rumus (Hasan, 2013):

$$
\mathrm{KK}=\frac{2 \mathrm{~S}}{\mathrm{~N} 1+\mathrm{N} 2}
$$

Keterangan:

K : Koefisien Kesepakatan.

2S : Sepakat, jumlah kode yang sama untuk objek yang sama.

N1 : jumlah kode yang dibuat oleh pengamat 1.

N2 : jumlah kode yang dibuat oleh pengamat 2 .
Hasil perhitungan uji reliabilitas intrumen menunjukan nilai rata-rata 0,881 yang termasuk ke dalan nilai dengan kategori sangat tinggi.

Teknik Analisis Data

Teknik analisis data dalam penelitian ini menggunakan Paired sample t-test. Paired sample t-test dilakukan dengan menggunakan analisis uji menggunakan program SPSS (Statistical Package for Social Science). Hasil analisis data diperoleh t-hitung=26,337.

\section{HASIL DAN PEMBAHASAN}

Pelaksanaan penelitian tentang efektivitas forum diskusi pada e-learning berbasis Moodle untuk meningkatkan partisipasi belajar ini diawali dengan kegiatan analisis masalah melalui wawancara secara tidak terstruktur kepada mahasiswa dan observasi terhadap pelaksanaan perkuliahan. Kedua teknik tersebut dilakukan untuk menggali seberapa pentingnya masalah ini untuk diangkat menjadi sebuah penelitian. Wawancara tidak terstruktur dengan mahasiswa digunakan untuk menggali partisipasi belajar dalam forum dikusi dikelas klasikal atau konvensional. Selain wawancara secara tidak terstruktur, dilakukan pula kegiatan observasi sebagai bentuk pretest terhadap 24 orang mahasiswa yang ada dalam kelas selama 1 hari. Wawancara dan observasi dilakukan diawal semester. Hasil pretest ini menunjukkan 9 orang memiliki partisipasi tinggi, 8 orang memiliki partisipasi sedang dan sisanya 7 orang memiliki partisipasi rendah. Selain untuk menggali partisipasi belajar mahasiswa, wawancara dan observasi juga dilakukan untuk menggali informasi tentang penggunaan aktivitas-aktivitas apa saja yang sering digunakan dalam e-learning serta minat mahasiswa mengikuti perkuliahan dengan tatap muka secara langsung maupun secara online menggunakan e-learning Moodle.

Penentuan pemberian perlakuan berupa penggunaan e-learning untuk aktivitas diskusi didasarkan pada beberapa penelitian-penelitian rujukan yang menunjukkan bahwa partisipasi belajar peserta didik akan meningkat apabila menggunakan pendekatan, metode, strategi maupun media pembelajaran yang baru. Salah satu penelitian yang sejalan dengan pernyataan tersebut ialah penelitian yang dilakukan oleh Rosmani (2016) yang menyatakan bahwa partisipasi belajar siswa mengalami peningkatan saat menggunakan model pembelajaran yang berbeda dari yang biasanya digunakan yaitu 
Fatmawati, Soraya

EFEKTIVITAS FORUM DISKUSI PADA E-LEARNING BERBASIS MOODLE UNTUK MENINGKATKAN ... REFLEKSI EDUKATIKA : Jurnal Ilmiah Kependidikan, Volume 9, Nomor 2, Juni 2019, hlm 210-216

portofolio. Sementara pada penelitian ini, perlakuan (treatment) yang dilakukan terhadap mahasiswa berupa pengajar menyelenggarakan metode diskusi dengan menggunakan bantuan elearning berbasis Moodle. Pengajar atau course creator membuat forum sebanyak 2 kali dengan 2 tema yang berbeda untuk nantinya mahasiswa dapat berdiskusi secara online. Forum diskusi ini dilakukan sebanyak 2 kali yaitu pada tanggal 1 Maret 2018 dan 15 Maret 2018. Pada diskusi pertama yang dilakukan secara online ini menunjukkan adanya peningkatan dari pretest yang telah dilakukan pada kelas klasikal begitu pula pada diskusi yang kedua. Peningkatan ini terlihat pada hasil dari keseluruhan posttest yang menunjukkan peningkatan dibandingkan pretest mereka.

Hasil analisis data dengan menggunakan t-test menunjukkan data sebagai berikut.

Tabel 1. Analisis Data Hasil Penelitian

\begin{tabular}{ccccc}
\hline No & Nama & Pre & Post & Peningkatan \\
\hline 1 & AWR & 2,5 & 5 & $85 \%$ \\
2 & NNH & 7 & 8,5 & $21 \%$ \\
3 & NI & 3 & 4,5 & $50 \%$ \\
4 & IF & 3 & 4,5 & $50 \%$ \\
5 & MSA & 9 & 10,5 & $16 \%$ \\
6 & RJ & 9,5 & 10,5 & $10 \%$ \\
7 & MHH & 7,5 & 9 & $20 \%$ \\
8 & HE & 2,5 & 5 & $85 \%$ \\
9 & MFS & 2,5 & 4,5 & $80 \%$ \\
10 & FSW & 8,5 & 10 & $17 \%$ \\
11 & LN & 4,5 & 6 & $33 \%$ \\
12 & TBE & 3 & 4,5 & $50 \%$ \\
13 & EA & 5 & 7 & $40 \%$ \\
14 & MH & 8 & 9,5 & $18 \%$ \\
15 & ADR & 2,5 & 5 & $85 \%$ \\
16 & LM & 5 & 7 & $40 \%$ \\
17 & NW & 6 & 8 & $33 \%$ \\
18 & R & 2,5 & 5 & $85 \%$ \\
19 & AFM & 5,5 & 7,5 & $36 \%$ \\
20 & SS & 7 & 9 & $22 \%$ \\
21 & NIS & 6,5 & 8 & $23 \%$ \\
22 & NAS & 9 & 10,5 & $16 \%$ \\
23 & MA & 8,5 & 10 & $17 \%$ \\
24 & AS & 6 & 8 & $33 \%$ \\
\hline
\end{tabular}

Hasil analisis data dengan menggunakan Uji-t menunjukkan bahwa t hitung adalah sebesar 26,337 kemudian $t$ hitung dibandingkan dengan $\mathrm{t}$ tabel $0,05=2.064$, karena $\mathrm{t}$ hitung $>\mathrm{t}$ tabel $(26,337>2.064)$ artinya Ha diterima. Hasil tersebut dapat diartikan bahwa partisipasi belajar mahasiswa dalam forum diskusi dengan menggunakan e-learning berbasis Moodle mengalami peningkatan jika dibandingkan dengan diskusi yang diselenggarakan di kelas konvensional atau klasikal secara tatap muka. Pengujian dengan uji-t ditentukan $\mathrm{df}=\mathrm{N}-1=24$ $1=23$ dengan taraf signifikansi 0,05 maka diperoleh $\mathrm{t}$ tabel $=2.064$. Proses pengujian hipotesis dengan uji-t menggunakan program SPSS (Statistical Package for Social Science).

Berdasarkan hasil akhir penelitian menunjukkan bahwa ada peningkatan partisipasi belajar mahasiswa dalam forum diskusi menggunakan e-learning berbasis Moodle. Peningkatan tersebut ditunjukkan melalui hasil uji $\mathrm{t}$ jika dibandingkan dengan forum diskusi di kelas konvensional. Hal tersebut dibuktikan dengan nilai rata-rata pretest sebesar 5,060 setelah diubah cara diskusinya dari yang bertatap muka secara langsung menjadi virtual dengan menggunakan e-learning berbasis Moodle hasil posttest menunjukkan peningkatan menjadi sebesar 6,938. Sehingga data menunjukkan adanya peningkatan sebesar 1,878 atau sebesar $37 \%$. Peningkatan partisipasi belajar mahasiwa tersebut dapat pula menjadi acuan bahwa eelarning berbasis Moodle dapat divariasikan penggunaannya tidak hanya sebatas pada aktivitas menggungah dan mengunduh materi, namun juga dapat digunakan sebagai tempat untuk berdiskusi dan aktivitas-aktivitas lainnya. Hal tersebut sesuai dengan hasil penelitian yang dilakukan oleh Ratnasati (2012) yang menemukan bahwa keaktifan mahasiwa mengalami peningkatan yang signifikan dalam kegiatan belajar mengajar saat menggunakan elearning yang kegiatannya meliputi mengunduh materi, forum diskusi dan pengerjaan kuis atau latihan soal. Sehingga, semakin banyak aktivitas yang dikerjakan oleh mahasiswa menggunakan e-learning akan semakin meningkat pula keaktifan dan partisipasi belajar mahasiswa.

\section{PENUTUP}

Simpulan

Berdasarkan penelitian yang telah dilakukan tentang efektivitas penggunaan forum diskusi menggunakan e-Learning berbasis Moodle untuk meningkatkan partisipasi belajar mahasiswa dapat disimpulkan bahwa aktivitas forum diskusi yang ada dalam e-learning berbasis Moodle ini mampu meningkatkan partisipasi belajar mahasiswa. Hal tersebut nampak dari pretest dan posttest yang menunjukkan adanya peningkatan nilai dari rata- 
Fatmawati, Soraya

EFEKTIVITAS FORUM DISKUSI PADA E-LEARNING BERBASIS MOODLE UNTUK MENINGKATKAN ... REFLEKSI EDUKATIKA : Jurnal Ilmiah Kependidikan, Volume 9, Nomor 2, Juni 2019, hlm 210-216

rata 5,060 menjadi 6,938 atau mengalami peningkatan sebesar $37 \%$.

Saran

Berdasarkan simpulan dari hasil penelitian ini, dapat diajukan beberapa saran yaitu (1) pengajar atau course creator perlu mengoptimalkan bentuk-bentuk aktivitas yang lain dalam Moodle agar mahasiswa lebih tertarik menggunakan e-learning. (2) pengajar perlu memotivasi mahasiswa untuk selalu aktif di dalam kelas untuk mengikuti perkuliahan baik elearing maupun di kelas konvensional atau klasikal. (3) pengajar atau course ceator perlu meningkatkan kemampuan di dalam pengelolaan course dalam e-learning agar e-elarning menjadi semakin menarik dan tidak dianggap hanya sebagai pelengkap perkuliahan.

\section{DAFTAR PUSTAKA}

Andrizal \& A. Arif. 2017. Pengembangan Media Pembelajaran Interaktif Pada Sistem Elearning Universitas Negeri Padang. Jurnal Inovasi, Vokasional dan Teknologi. 17 (2): 1-10.

Firmansyah, M.B. 2017. Model Pembelajaran Diskusi Berbasis Perilaku Berliterasi Untuk Keterampilan Berbicara. Jurnal Ilmiah Edukasi \& Sosial. 8 (2): 119125.

Gafur, A. 2012. Desain Pembelajaran: Konsep, Model dan Aplikasinya Dalam Perencanaan Pelaksanaan Pembelajaran. Yogyakarta: Penerbit Ombak.

Hakim, A.B. 2016. Efektifitas Penggunaan ELearning Moodle, Google Classroom Dan Edmodo. Jurnal I-Statement. 2 (1) $: 1-6$.

Hasan, I. 2013. Analisis Data Penelitian Dengan Statistika. Jakarta: Bumi Aksara.

Ibrahim, N. \& Ishartiwi. 2017. Pengembangan Media Pembelajaran Mobile Learning Berbasis Android Mata Pelajaran IPA Untuk Siswa SMP. Jurnal Refleksi Edutika. 8 (1): 80-88.
Luritawaty, I.P. 2016. Upaya Meningkatkan Kemampuan Komunikasi Matematis Melalui Metode Diskusi Berbantuan Microsoft Office Excel. Jurnal Pendidikan Matematika STKIP Garut. 5 (3): 213-222.

Mayasari, N. 2016. Penerapan Model Pembelajaran CTL (Contextual Teaching And Learning) Untuk Meningkatkan Minat Dan Partisipasi Belajar Mahasiswa. Jurnal Ilmiah Pendidikan Matematika (JIPM). 4 (2): 122-126.

Mustajab, Sriyono \& Siska D.F. 2012. Penerapan Metode Pembelajaran Cooperative Script Untuk Meningkatkan Partisipasi Belajar Siswa Kelas VIII A Smp Negeri 2 Karanggayam Tahun Pelajaran 2012/2013. Jurnal Radiasi. 1 (1): 37-40.

Panjaitan, T.D. 2017. Pemanfaatan Kartu Kendali Tugas Untuk Meningkatkan Motivasi Belajar Siswa. Jurnal Global Edukasi. 1 (3): 1-6.

Ratnasari, A. 2012. Studi Pengaruh Penerapan ELearning Terhadap Keaktifan Mahasiswa Dalam Kegiatan Belajar Mengajar Studi Kasus Universitas Mercu Buana Jakarta. Jurnal Fakultas Hukum UII. 13 (1): 10-16

Rosmani. 2016. Peningkatan Partisipasi Belajar Siswa Kelas IV Dengan Model Pembelajaran Berbasis Portofolio Pada Mata Pelajaran PKn. Jurnal Educatio. 2 (1): $21-28$

Rulviana, V. 2018. Implementasi Media Edmodo Dalam Mata Kuliah Pengembangan Kurikulum Sekolah Dasar. Jurnal Refleksi Edutika. 8 (2): 205-208.

Surdjono, H.D. 2013. Membangun Course ELearning Berbasis Moodle Edisi Kedua. Yogyakarta: UNY Press. 